\title{
Managing Rewards to Enhance Customer Lifetime Value
}

\author{
Enny Kristiani ${ }^{1}$, Ujang Sumarwan ${ }^{1,2}$, Lilik Noor Yuliati ${ }^{1,2}$ \& Asep Saefuddin ${ }^{1,3}$ \\ ${ }^{1}$ Graduate School of Management and Business, Bogor Agricultural University, Indonesia \\ ${ }^{2}$ Department of Family and Consumer Science, Bogor Agricultural University, Indonesia \\ ${ }^{3}$ Department of Statistics, Bogor Agricultural University, Indonesia \\ Correspondence: Enny Kristiani, Graduate School of Management and Business, Bogor Agricultural University, \\ Jl Padjajaran, Bogor, Indonesia. Tel: 62-8-1198-5443. E-mail: enny.kristiani@yahoo.com
}

\author{
Received: October 20, 2013 Accepted: November 11, 2013 Online Published: December 29, 2013 \\ doi:10.5539/ass.v10n2p84 URL: http://dx.doi.org/10.5539/ass.v10n2p84
}

\begin{abstract}
The goal of loyalty reward program is to retain customers who are profitable to the organization. However most airlines have very little understanding of their customers yet have a little knowledge about their most valuable passengers. This study is aimed to analyze financial aspects of customer value to the company in the context of aviation loyalty reward program in Indonesia. Financial value of customers is analyzed using CLV approach. Modeling of financial value of the members to the airline is developed by performing regression analysis of CLV against RFM and the associated socio-demographic characteristics of the members. This study used secondary data of customer profiles and financial transactions of the Garuda Frequent Flyer members in 2012. The empirical findings observed in this study explain that the financial value of the frequent flyer members to the airline is influenced by RFM, Gender, Age, and Frequent Flyer Tier levels. It is also found that the RFM valuation is aligned with CLV analysis. The result contributes to the knowledge of aviation loyalty program by improving the effectiveness from the aspect of capitalizing on the lifetime value of the members, and to the industry in designing proper marketing strategy and implementing accurate marketing functions in term of Frequent Flyer Program.
\end{abstract}

Keywords: loyalty reward program, profitability, RFM, CLV

\section{Introduction}

The best known example of successful loyalty programs in airline industry is a frequent flyer program (FFP) (Kim et al., 2001; Browne et al., 1995). The marketing strategy is used by airline industries to maximize their profit and retain their loyal customers. Having grown in exponential expansion, FFPs are notorious as the largest membership of loyalty program with more than 120 million members enrolled in one or more of the 200 FFPs globally (McCaughey \& Behrens, 2011). FFP awards generally reward loyal (and frequent) customers in the form of loyalty currency which can be used for free flights, upgrades, shop products, and other services. Having considered as a part of payment systems, frequent flyer miles represent one of the world's most popular currencies (Dreze \& Nunes, 2004).

However the effectiveness of FFP has been argued because of the huge operating cost involved (Yang \& Liu, 2003) whereas loyalty and profitability are not always aligned considering most loyal customers are not necessarily the most profitable (Reinartz \& Kumar, 2000). How do the programs affect beneficial outcomes for the airline? In the meanwhile, airline industry commonly offers a generic benefit scheme to their FFP members (Tirenni et al., 2007). The "one size fits all" strategy is indeed very costly yet ineffective because each type of customer segmentation has particular preferences pertaining to the benefits (Suzuki, 2003; Martin et al., 2011). In general, most airlines have very little understanding of their FFP members and have yet little knowledge about their most valuable customers (O'Connel, 2009). They mistakenly use inaccurate models for customer valuation which is simply based on miles flown regardless of ticket fare (Tirenni et al., 2007; Yang \& Liu, 2003).

In the context of customer equity, consumers generate values to the organization by means of financial and non-financial contributions. Based on the concept of customer lifetime value (CLV), financial value to the organization is typically defined as business worth of nominal profit generated by customer. In the context of service organization such as airline industry, the value derived from customers greatly influences the profitability of airlines. In the airlines industry, the customer values have normally been determined only by current tier of the 
loyalty program rather than lifetime values. As a matter of a fact, the highest tier' members are not necessarily the most profitable nor loyal customers to the airline (Tirenni et al., 2007). These kind of members might not generate profitable revenue to the airline yet very costly in serving their premium services. Therefore, it is crucial for airline to accurately identify its valuable customers and effectively target them to sustain long-term relationship benefit of the firm as well as of the customers.

While FFP has attracted a great deal of attention in the transportation and marketing literatures, there has been relatively little formal modeling of FFP by academics (Basso et al., 2009). This study becomes unique by exploring actual FFP data from an airline to determine the financial value of FFP members of an established airline. Research with access to actual FFP data from an airline is still uncommon (McCaughey \& Behrens, 2011). Meanwhile, to our knowledge, there has been no research on frequent flyer program of Indonesian airlines. Hence, the financial value of the FFP members to the airline has not been thoroughly observed yet. This study develops modeling to identify the monetary value of the FFP members based on their consuming behavior.

\subsection{Loyalty Reward Program (LRP)}

The key-roles of the LRP are "loyalty" as the primary goal of loyalty program, and "reward" as the key instrument for attaining it (Yuheng, 2011). The basic concept of LRP is to enhance customers' long-term profitability in term of customers' lifetime value as a form of equity (Yuheng, 2011). Reward has proven strongly in affecting customers' making decision and also their behavior changes as well (Gomez et al., 2006). LRP has been increasingly applied in many industries. The US loyalty marketing industry, a $\$ 6$ billion market, contains more than 2,000 LRPs, and 90\% of Americans in at least one loyalty program (Berman, 2006).

Based on the basic type of the LRP (Ho et al., 2009), frequent flyer is a Type III of customer loyalty program in which members receive points (free miles) based on cumulative purchases. As a Type III of the program, FFP provides more indicators of consumers' purchasing behavior. Therefore, a Type III program induces customer loyalty especially when the rewards align with customers' interests.

\subsection{Loyalty \& Profitability}

A successful loyalty program increases value-proposition of the product, retains loyalty and hence preserves the profitability from the customers (Kumar \& Petersen, 2005). Loyalty reward program can be significantly costly for the organization despite the fact that loyal customers are not always generating profit to the firm in non-contractual settings (Reinartz \& Kumar, 2000). Airline business is classified as a non-contractual setting as the time at which a customer ended the relationship with the airline is unknown. FFP costs to the airline by offering the benefits including upgrade and free flight tickets or other advantages in check-in, priority on the waiting lists of overbooked flights, extra baggage allowances or business lounges access. These benefits cost to the airline at a range from $\$ 3$ to $\$ 20$ per member per year and involve about $\$ 2 \mathrm{M}-\$ 12 \mathrm{M}$ to start up the program (O’Connel, 2009).

Because profitability is the final outcome of business performance, it is important for airline to determine whether FFP members do add financial value to the airline considering profitable customers are not necessarily loyal customers. Basso et al. (2009) found the possibility that even with higher ticket price, FFPs ultimately erode airline profitability. The fact that prices and profits will move in opposite directions with FFP caught airline in a prisoner dilemma type situation. Airline must align its business objective by reducing the costs to running FFP while maximizing the lifetime value of its members in order to define the marketing effort and to target members accurately.

\subsection{RFM Analysis}

RFM analysis depends on Recency (R), Frequency (F), and Monetary (M) variables based on customer' transaction profiles. Previous scholars (Hughes, 1994; Lin et al., 2010) believed that RFM is the most accurate method to predict customer future behavior compared to any possible demographic combinations because RFM exactly measures what people do: when they buy, how often they buy, how much they buy. RFM Score represents customer' purchasing behavior and his/her profitability value for the company (Wei et al., 2010). From the view of the consuming behavior, RFM Score is related to the strength of customer relationship and hence, it also represents customer loyalty (Schijns \& Schroder, 1996).

Traditional literature believes that the three variables of the RFM model are equal in the importance; therefore, the weights of the three variables should be identical (Hughes, 1994). On the other hand, some literatures (Liu \& Shih, 2005; Shen \& Chuang, 2009) indicate that the three variables are different in the importance depending on the characteristic of industry. Thus, the weights of the three variables are not equal. In this research, the weight of the variables are defined using Principal Component Analysis (PCA), a statistical approach that can be used to 
analyze interrelationships among a large number of variables and to explain these variables in terms of their common underlying dimensions (Hair et al., 2010). The model of CLV RFM Score is represented by the following empirical model.

$$
\mathrm{Y}=\mathrm{a}(\mathrm{R})+\mathrm{b}(\mathrm{F})+\mathrm{c}(\mathrm{M})
$$

Where,

a,b,c=the weight of Recency, Frequency, and Monetary, respectively

$\mathrm{R}=$ Recency

$\mathrm{F}=$ Frequency

$\mathrm{M}=$ Monetary

\subsection{Customer Lifetime Value (CLV)}

A basic tenet of the evaluation of marketing strategy is that marketing efforts should be referred to the customer lifetime value (Rust et al., 2000; Blattberg et al., 2001; Jain \& Singh, 2002). Hence, the allocation of marketing resources should focus on the enhancement of the expected customer lifetime value.

CLV is defined as the expected lifetime value of customer. It represents the present value of all the future revenues obtained from customers over their life of relationship with an organization (Pfeifer et al., 2005; Reinartz \& Kumar, 2000). CLV serves as an accurate indicator of the future customer profitability by predicting expected revenues generated by the customer. As noted by Reinartz \& Kumar (2000), CLV is the most important stage in selecting the right customers to be retained in addition to the profitable lifetime duration for non-contractual relationship. Consequently, CLV focuses on financial benefits created from the retention of customers. CLV can be used to guide the firm's acquisition and retention activities of its customers (Blattberg et al., 2009). CLV approach provides guidance for organization to segment its customers based on their profitability generated for the firm.

The components determined CLV include the relationship duration (the likelihood of customer has a relationship with the organization in period of $t$ ), the expected revenues generated by customer during the tenure with the organization in period of $t$, the expected costs borne by organization in maintaining the relationship in period of $t$, and the discounted rate. The formulation of expected CLV according to Kumar V et al. (2008) is as follows:

$$
C L V_{i}=\sum_{t=1}^{t} P(\text { Active })_{i t} x \frac{\text { AMGC }_{i t}}{(1+d)^{t}}-\sum_{t=1}^{T} M_{i t} x\left(\frac{1}{1+d}\right)^{t}-A_{t}
$$

Where,

$\mathrm{AMGC}_{\mathrm{it}}=$ Average Contribution margin brutto customer i in purchase occasion $\mathrm{t}$

$\mathrm{M}=$ marketing cost

$\mathrm{A}=$ acquisition cost

$\mathrm{i}=$ customer index

$\mathrm{t}=$ time period

$\mathrm{T}=$ period beyond $\mathrm{t}$

$\mathrm{d}=$ discounted rate

$\mathrm{P}(\text { Active })_{\mathrm{it}}=$ probability customer i' activity in period $\mathrm{t}$, or expected life of customer $\mathrm{i}$.

The value of expected life of customer depends on the retention rate of the customer, $r$ (Reichheld, 1996).

$$
P(\text { active })=\frac{1}{1-r}
$$

The retention rate (r) can be found based on the following formula (Kumar, 2005):

$$
\mathrm{r}=\left(\frac{\mathrm{T}}{\mathrm{N}}\right)^{n}
$$


Where,

$\mathrm{n}=$ total purchase in time observation period

$\mathrm{T}=$ time when last purchase performed by customer

$\mathrm{N}=$ observed time

CLV is calculated for each homogeneous segmenting customer by estimating customer future value with analyzing trend of customer. One variant of the CLV estimation models is the RFM framework commonly used in direct marketing in which the probability of customers' future purchases is based on the recency, frequency and monetary value of their past transactions. These RFM probabilities are then used to classify customers according to their profit potential. The RFM approach offers a potential solution to the problems associated with predicting CLV and gives direct marketers input on customer profitability and relationship management issues.

\subsection{Modeling Financial Value of FFP Members to the Airline}

Regression is used to analyze the associated variables to CLV, especially RFM and related socio-demographic characteristics of the members, including: Gender, Age and Frequent Flyer Tier level. The empirical model is:

$$
\log \mathrm{Y}=\beta_{0}+\beta_{1} \mathrm{X}_{1}+\beta_{2} \mathrm{X}_{2+} \beta_{3} \mathrm{X}_{3+} \beta_{4} \mathrm{D}_{1+} \beta_{5} \mathrm{D}_{2+} \beta_{6} \mathrm{D}_{3+} \xi_{\mathrm{I}}
$$

Where,

\section{Y: CLV}

$\beta_{0}:$ intercept

$\beta_{1 \sim 6}:$ regression coefficient

$\mathrm{X}_{1}: \mathrm{RFM}$

$\mathrm{X}_{2}$ : Age

$\mathrm{X}_{3}$ : Gender, dummy variable $($ Male $=0$, Female $=1$ )

$\mathrm{D}$ is a dummy of Tier-variable with Blue tier membership for a reference category

$\mathrm{D}_{1}$ : Dummy Silver-Tier [Tier $\mathrm{S}$ ]

$\mathrm{D}_{2}$ : Dummy Gold-Tier [Tier G]

$\mathrm{D}_{3}$ : Dummy Platinum-Tier [Tier P]

$$
\xi_{\mathrm{i}} \text { : Error }
$$

The rest of the paper is structured as follows. Section 2 describes the data \& method, followed by Section 3 for the empirical result \& discussion. Finally, Section 4 concludes the study.

\section{Data \& Variable}

\subsection{Sampling Technique}

The focus in this research is on the modeling of financial value of FFP members to an airline in Indonesia. In this study, the loyalty program' customer value to the airline is referred to FFP of a state owned airline in Indonesia, Garuda Indonesia. The data was sampled from Garuda Frequent Flyer (GFF) members registered up to 2012. The sampling technique is a combination of stratified random and systematic sampling. The optimum sample size (n) is 9,431 out of total members $(594,302)$ according to Krejcie \& Morgan (1970) for $95 \%$ of confidence level and 0.01 of margin error.

\subsection{Variables}

The variables in this study refer to three measurement on RFM score (Recency, Frequency and Monetary) and seven measurements on CLV developed by Kumar V. et al. (2008) and Reichheld (1996), which are probability lifetime duration of customer (P), average revenue generated by customer (AMGC), marketing cost (M), acquisition cost (A), time period, discounted rate, customer retention rate, $r$ (as a function of recency, frequency and period of time). 
Table 1. Variables RFM and CLV

\begin{tabular}{|c|c|c|}
\hline Construct & Measurement & Scale \\
\hline RFM & $\begin{array}{l}\text { Recency+Frequency+Monetary Using Principal Component Analysis (PCA) } \\
\text { for the weights }\end{array}$ & Ratio \\
\hline Recency & $\begin{array}{l}\text { Time period since the last purchase. It was transformed to ratio by assigning } \\
\text { point based on the quintiles concept. }\end{array}$ & Ratio \\
\hline Frequency & The number of purchase transactions that a customer has made within 2012 & Ratio \\
\hline Monetary & $\begin{array}{l}\text { Revenues of the company from each member collected in } 2012 \text { (based on } \\
\text { customer's transaction in purchasing the tickets) and standardized using } \\
\text { z-score }\end{array}$ & Ratio \\
\hline $\begin{array}{l}\text { Customer Lifetime } \\
\text { Value }\end{array}$ & See equation (2) & Ratio \\
\hline $\mathrm{P}$ (Active) & Probability customer i' activity in period t or the expected life of customer i. & Ratio \\
\hline $\begin{array}{l}\text { AMGC } \\
\text { Contribution } \\
\text { Margin) }\end{array}$ & IDR (Indonesian Currency) & Ratio \\
\hline $\begin{array}{l}\text { MC } \quad \text { (Marketing } \\
\text { Cost) }\end{array}$ & IDR (Indonesian Currency) & Ratio \\
\hline Acquisition Cost & IDR (Indonesian Currency) & Ratio \\
\hline Discounted rate & Percentage & Ratio \\
\hline
\end{tabular}

\section{Analysis \& Discussion}

\subsection{RFM Score \& CLV Analysis}

There were 60,068 total flight transactions executed by the 9,431 members during 2012. The frequency of transaction per member was on the range of 0-138 times. Total generated revenue from these ticket payments is defined as total monetary amount made by the customers to the airline. The airline applies sixteen different fare types per flight hence the generated revenue per transaction is calculated based on each ticket fare. This monetary value is financial revenue and standardized using $\mathrm{z}$-score.

By having $89.5 \%$ of the total variance, the equation (1) of the weighted PCA for RFM score is found as below:

$$
\text { RFM Score }=1.009(\mathrm{R})+0.546(\mathrm{~F})+0.55(\mathrm{M})
$$

Based on the above equation, the maximum importance of the members' transaction behavior to the airline is recency. Meanwhile, monetary and frequency have a slight difference in affecting the profitability value for the airline. The fact that recency is the most important factor representing GFF member's purchasing behavior and their profitability is in accordance with the previous studies of Reinartz \& Kumar (2000) and Tirenni et al. (2007). Frequency as the least important component of RFM score was also identified by Reinartz \& Kumar (2000) on their non-contractual setting research.

The range of CLV value is IDR-13,874 up to IDR 535,572,869 with IDR 15,397,244 as the average value and standard deviation $27,945,127$. Negative value of CLV means that the airline incurred higher cost in maintaining the relationship (cost of marketing and acquisition) rather than obtaining revenue generated by the member. The airline should not continue maintaining this type of membership. On the other hand, the members with low CLV should be enhanced to maximize return on marketing and acquisition investments. However, in general a FFP member contributes around 15 million IDR to the company.

Further step, a comparison between RFM and CLV is performed according to the segmentation structure. There is a positive correlation between RFM and CLV as indicated in Figure 1 below. 


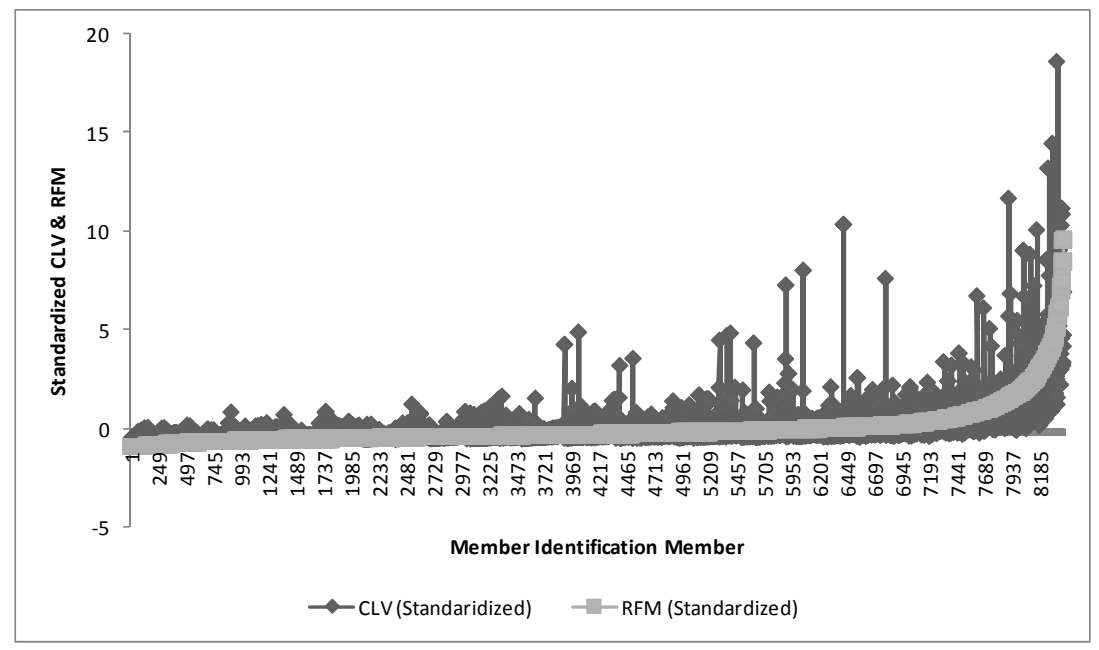

Figure 1. RFM and CLV of the GFF members

The Pearson Correlation is $71.5 \%$ indicating a strong positive correlation between RFM and CLV.

In summary, the financial valuation of the members based on RFM clustering is strongly proven by the CLV valuation. The following section will explore on the modelling of financial value of the members based on regression analysis.

\subsection{Regression Analysis}

Equation (5) of the model of financial value (CLV) of FFP members to the airline against its associated RFM components and demographic variables (Age, Gender, Frequent Flyer Tier level), is represented by the regression equation as shown below:

$\log C L V=6.79+0.00204$ RFM+0.000294 Age-0.00620 Gender+0.211 Tier S+0.423 Tier G+1.12 Tier P

Hence,

$\mathrm{CLV}=\operatorname{Exp}[6.79+0.00204 \mathrm{RFM}+0.000294$ Age-0.00620 Gender +0.211 Tier $\mathrm{S}+0.423$ Tier $\mathrm{G}+1.12$ Tier P]

By having R-square $99.8 \%$, the above model explains $99.8 \%$ of the total variation of the data. Hence, the regression model meets a goodness of fit. The t-Test result of the model is shown below.

Table 2. Significant test (t-Test)

\begin{tabular}{llllll}
\hline Predictor & Coef & SE Coef & T & P & VIF \\
\hline Constant & 6.78933 & 0.00072 & 9380.19 & 0.000 & \\
RFM & 0.00203857 & 0.00002187 & 93.19 & 0.000 & 1.1 \\
Age & 0.00029413 & 0.00001358 & 21.65 & 0.000 & 1.6 \\
Gender & -0.0062042 & 0.0002341 & -26.50 & 0.000 & 1.6 \\
SILVER & 0.210688 & 0.000297 & 708.57 & 0.000 & 1.2 \\
GOLD & 0.422803 & 0.000308 & 1370.94 & 0.000 & 2.5 \\
PLATINUM & 1.11996 & 0.00149 & 750.05 & 0.000 & 1.0 \\
\hline
\end{tabular}

$\mathrm{S}=1.00004 ; \mathrm{R}-\mathrm{Sq}=99.8 \% ; \mathrm{R}-\mathrm{Sq}(\mathrm{adj})=99.8 \%$

As shown on the significant test table, three variables (RFM, age, and tier levels) contribute positively to the CLV value. As member getting older and having higher RFM or tier level, the CLV increases.

Compared to Blue tier member, the average CLV effect of Silver tier member is $23.491 \%$ higher whereas the difference in the average CLV effect between the Gold and Platinum members is $52.653 \%$ and $206.48 \%$, respectively. Hence, the higher of the tier level is always followed by the higher amount of monetary value of the 
member. Platinum tier level has the greatest impact on the CLV followed by Gold, Silver and Blue. The result is supported by the fact that members with higher level of tier do more profitable transactions than the lower tier. Member is qualified for a certain tier only if he/she meets the condition precedent, the accumulated miles per year. Therefore, to enhance the CLV of the member, the airline should encourage the member to do more and more flight transactions.

In relation to gender, male members are more valuable than female since they produce higher CLVs to the airline. The CLV of male member is $0.062 \%$ higher than that of female member.

The higher value of RFM is always followed by the higher value of customer lifetime (CLV). By doubling-up the RFM, the CLV will grow 0.2 percent higher. Amongst the components of RFM (equation 6), recency is the most important factor affecting CLV. Therefore, the newer the member of FFP makes a flight transaction with the airline the higher the value generated by the member to the airline. In the meanwhile, frequency and amount of purchase are found contributing less to CLV than recency.

The increment of age also enhances the CLV but much less significant than the impact of RFM to the CLV. Based on the cross tabulation analysis between RFM score and age of the members, the peak of contribution is given by members whose age on the range 46-55 and decreasing for members beyond 56 years old. By transaction enhancement of members in their 30-40s, CLV will be increased. The populations of these members are quite significant as presented in Figure 2.

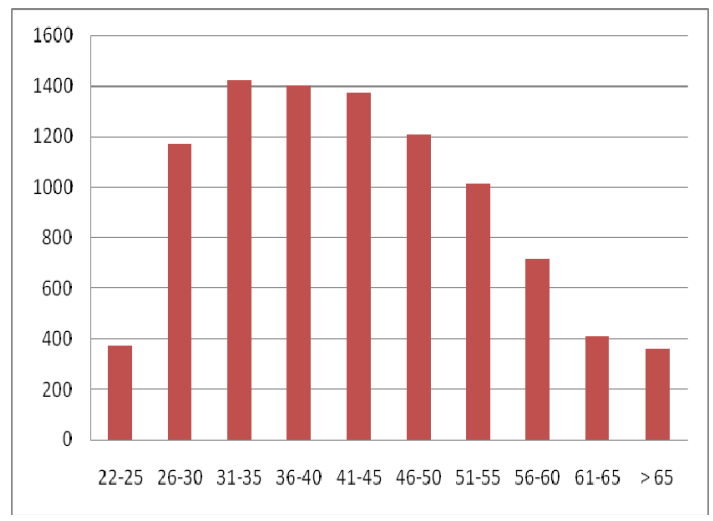

Figure 2. Age groups

\section{Conclusion}

The result shows the financial value of the GFF members is primarily affected by the structure of FFP (Platinum, Gold, Silver and Blue tier levels). Platinum tier status is the most important variable in determining the value of CLV. The higher the level of FFP member tier is, the higher the CLV will be generated. Hence the airline needs to treat members differently based on the tier level to further enhance the CLV.

The airline should enhance the RFM of the FFP members by assign maximum importance to recency, less monetary, and the least to frequency. The marketing strategy and resource allocation should be aligned to the degree of RFM importance.

The marketing strategy should also support the enhancement of CLV by accurate marketing approach with regard to gender and age variation. Male and older members tend to be more valuable by providing higher CLV.

\section{References}

Basso, L. J., Clements, M. T., \& Ross, T. W. (2009). Moral Hazard and Customer Loyalty Programs. American Economic Journal Microeconomics, 1(1), 101-123. http://dx.doi.org/10.1257/mic.1.1.101

Berman, B. (2006). Developing an effective customer loyalty program. California Management Review, 49(1), 123-148. http://dx.doi.org/10.2307/41166374

Blattberg, R. C., Getz, G., \& Thomas, J. S. (2001). Customer Equity: Building \& Managing Relationships as Valuable Assets. Boston, MA: Harvard Business School Press.

Blattberg, R. C., Malthouse, E. C., \& Neslin, S. A. (2009). Customer Lifetime Value: Empirical Generalizations and Some Conceptual Questions. J. of Interactive Marketing, 23, 157-168. 
http://dx.doi.org/10.1016/j.intmar.2009.02.005

Browne, W. G., Toh, R. S., \& Hu, M. Y. (1995). FFP: The Australian Experiences. Transportation Journal, 35(2), $35-44$.

Dreze, X., \& Nunes, J. C. (2004). Using Combined-Currency Prices to Lower Consumer' Perceived Cost. J. of Marketing Research, 41(1), 59-72. http://dx.doi.org/10.1509/jmkr.41.1.59.25085

Global Flight SARL. (2013). Frequent Flyer Program Listing. Retrieved August 5, 2013, from http://www.globalflight.net

Gomez, B. G., Arranz, A. G., \& Cillan, J. G. (2006). The role of loyalty programs in behavioural \& affective loyalty. J. of Consumer Marketing, 23(7), 389-396. http://dx.doi.org/10.1108/07363760610712920

Hair, J. F. J., Black, W. C., Babin, B. J., \& Anderson, R. E. (2010). Multivariate Data Analysis A Global Perspective (7th ed.). New York: Pearson.

Hughes, A. M. (1994). Boosting Response with RFM. J. of Marketing Tool, 3(3), 4-5.

Jain, D., \& Singh, S. S. (2002). Customer lifetime value research in marketing: A review and future directions. $J$. of Interactive Marketing, 16(2), 34-46. http://dx.doi.org/10.1002/dir.10032

Kim, B. D., Shi, M., \& Srinivasan, K. (2001). Reward programs \& tacit collusion. J. of Marketing Science, 20(2), 99-119. http://dx.doi.org/10.1287/mksc.20.2.99.10191

Krejcie, R. V., \& Morgan, D. W. (1970). Determining Sample Size for Research Activities. Educational \& Psychological Measurement, 30, 607-610.

Kumar, V. (2008). Managing Customers for profit. New Jersey: Pearson Education, Inc.

Kumar, V., \& Petersen, J. A. (2005). Using a Customer-Level Marketing Strategy to Enhance Firm Performance: A Review of Theoretical and Empirical Evidence. J. of Academy of Marketing Science, 33(4), 504-519. http://dx.doi.org/10.1177/0092070305275857

Kumar, V., Venkatesan, R., Bohling, T., \& Beckmann, D. (2008). The Power of CLV: Managing Customer Lifetime Value at IBM. J. of Marketing Science, 27(4), 585-599. http://dx.doi.org/10.1287/mksc.1070.0319

Lin, S. Y., Wei, J. T., \& Wu, H. H. (2010). A Review of the application of RFM model. J. of Business Management, 4(19), 4199-4206.

Liu, D. R., \& Shih, Y. Y. (2005). Integrating AHP and data mining for product recommendation based on customer lifetime value. J. of Information \& Management, 42(1), 387-400. http://dx.doi.org/10.1016/j.im.2004.01.008

Martin, J. C., Roman, C., \& Espino, R. (2011). Evaluating Frequent Flyer Programs from the air passengers' $\begin{array}{llllll}\text { perspective. } J . & \text { of } & \text { Air } & \text { Transport } & \text { Management, } & \text { 17(1), }\end{array}$ http://dx.doi.org/10.1016/j.jairtraman.2011.02.008

McCaughey, N. C., \& Behrens, C. (2011). Paying for Status? The effect of frequent flier program member status on air fare choice. Working Paper. Department of Economics, Monash University.

O’Connell, J. F. (2009). Frequent Flyer Programs. Working Paper. Presented to Garuda Indonesia in December 2009.

Pfeifer, P. E., \& Bang, H. (2005). Non-parametric Estimation of Mean Customer Lifetime Value. J. of Interactive Marketing, 19, 48-66. http://dx.doi.org/10.1002/dir.20049

Reichheld, F. (1996). The Loyalty Effect: The Hidden Force behind Growth, Profits, and Lasting Value. Boston: Harvard Business School Press.

Reinartz, J. W., \& Kumar, V. (2000). On the Profitability of Long-Life Customers in a Non-contractual Setting: An Empirical Investigation and Implications for Marketing. J. of Marketing, 64(4), 17-35. http://dx.doi.org/10.1509/jmkg.64.4.17.18077

Richard, H., Huang, L., Huang, S., Lee, T., Rosten, A., \& Tang, C. S. (2009). An approach to develop effective customer loyalty programs. J. of Managing Service Quality, 19(6), $702-720$. http://dx.doi.org/10.1108/09604520911005080

Rust, R., Zeithaml, V., \& Lemon, K. N. (2000). Driving Customer Equity: How Customer Lifetime Value Is Reshaping Corporate Strategy. New York: The Free Press.

Schijns, J. M. C., \& Schroder, G. J. (1996). Segment selection by relationship strength. J. of Direct Marketing, 
4(19), 4199-4206.

Shen, C. C., \& Chuang, H. M. (2009). A study on the applications of data mining techniques to enhance customer lifetime value. WSEAS Transactions on Information Science and Applications, 6(2), 319-328.

Suzuki, Y. (2003). Airline frequent flyer programs: Equity and attractiveness. Transportation Research Part E, 39, 289-304. http://dx.doi.org/10.1016/S1366-5545(03)00003-6

Tirenni, G., Labbi, A., Berrospi, C., Elisseeff, A., Bhose, T., Pauro, K., \& Poyhonen, S. (2007). Customer Equity and Lifetime Management (CELM). Finnair Case Study. J. of Marketing Science, 26(4), 553-565. http://dx.doi.org/10.1287/mksc. 1060.0249

Wei, J. T., Lin, S. Y., \& Wu, H. H. (2010). A Review of the Application of RFM Model. African Journal of Business Management, 4(19), 4199-4206.

Yang, J., \& Liu, A. (2003). Frequent Flyer Program: A case study of China airline's marketing initiative-Dynasty $\begin{array}{lllll}\text { Flyer Program. J. of Tourism } & \text { Management, } & \text { 24(1), }\end{array}$ http://dx.doi.org/10.1016/S0261-5177(03)00007-4

Yuheng, C. (2011). Rewards-Supply Aggregate Planning in the Management of Loyalty Reward Program-A Stochastic Linear Programming Approach. [Dissertation]. Carleton University, Ontario, Canada. (Published No. UMI NR83243)

\section{Copyrights}

Copyright for this article is retained by the author(s), with first publication rights granted to the journal.

This is an open-access article distributed under the terms and conditions of the Creative Commons Attribution license (http://creativecommons.org/licenses/by/3.0/). 